Pesq. Vet. Bras. 29(7):545-551, julho 2009

\title{
Efficacy of a gE-deleted, bovine herpesvirus 1 (BoHV-1) inactivated vaccine ${ }^{1}$
}

\author{
Alessandra D. Silva'2,3, Paulo A. Esteves ${ }^{2,4}$, Diogenes Dezen ${ }^{2,3}$, Anna P. \\ Oliveira ${ }^{2,5}$, Fernando R. Spilki6, Fabrício S. Campos $^{5}$, Ana C. Franco ${ }^{5}$ and \\ Paulo M. Roehe $2,3,5^{*}$
}

\begin{abstract}
Silva A.D., Esteves P.A., Dezen D., Oliveira A.P., Spilki F.R., Campos F.S., Franco A.C. \& Roehe P.M. 2009. Efficacy of a gE-deleted, bovine herpesvirus 1 (BoHV1) inactivated vaccine. Pesquisa Veterinária Brasileira 29(7):545-551. Instituto de Pesquisas Veterinárias Desidério Finamor, Fepagro Saúde Animal, Estrada do Conde 6000, Cx. Postal 47, Eldorado do Sul, RS 92990-000, Brazil. E-mail: proehe@gmail.com

Bovine herpesvirus type 1 (BoHV-1) is recognized as a major cause of economic losses in cattle. Vaccination has been widely applied to minimize losses induced by BoHV-1 infections. We have previously reported the development of a differential BoHV1 vaccine, based on a recombinant glycoprotein $\mathrm{E}(\mathrm{gE})$-deleted virus $(265 \mathrm{gE})$ ). In present paper the efficacy of such recombinant was evaluated as an inactivated vaccine. Five BoHV-1 seronegative calves were vaccinated intramuscularly on day 0 and boostered 30 days later with an inactivated, oil adjuvanted vaccine containing an antigenic mass equivalent to $10^{7.0}$ fifty per cent cell culture infectious doses $\left(\mathrm{CCID}_{50}\right)$ of $265 \mathrm{gE}$-. Three calves were kept as non vaccinated controls. On day 60 post vaccination both vaccinated and controls were challenged with the virulent parental strain. No clinical signs or adverse effects were seen after or during vaccination. After challenge, 2/5 vaccinated calves showed mild clinical signs of infection, whereas all non vaccinated controls displayed intense rhinotracheitis and shed virus for longer and to higher titres than vaccinated calves. Serological responses were detected in all vaccinated animals after the second dose of vaccine, but not on control calves. Following corticosteroid administration in attempting to induce reactivation of the latent infection, no clinical signs were observed in vaccinated calves, whereas non vaccinated controls showed clinical signs of respiratory disease. In view of its immunogenicity and protective effect upon challenge with a virulent BoHV -1 , the oil adjuvanted preparation with the inactivated $265 \mathrm{gE}^{-}$recombinant was shown to be suitable for use as a vaccine.
\end{abstract}

INDEX TERMS: Bovine herpesvirus type 1, BoHV-1, recombinant vaccine, inactivated vaccine.

\footnotetext{
${ }^{1}$ Received on December 9, 2008.

Accepted for publication on March 10, 2009.

${ }^{2}$ Equipe de Virologia, Instituto de Pesquisas Veterinárias Desidério Finamor (CPVDF), Fepagro Saúde Animal, Estrada do Conde 6000, Cx.Postal 47, Eldorado do Sul, RS 92990-000, Brazil. *Corresponding author: proehe@gmail.com

${ }^{3}$ Programa de Pós-Graduação em Ciências Veterinárias (PPGCV), Universidade Federal do Rio Grande do Sul (UFRGS), Av. Bento Gonçalves 9090, Porto Alegre, RS 91540-000, Brazil.

${ }^{4}$ Embrapa Suínos e Aves, BR153, Km 110, Vila Tamanduá, Cx.Postal 21, Concórdia, SC 89700-000, Brazil.

${ }^{5}$ Instituto de Ciências Básicas da Saúde, UFRGS, Rua Sarmento Leite 500, Porto Alegre, RS 90050-170.

${ }^{6}$ Instituto de Ciências da Saúde, Centro Universitário Feevale, Campus II, RS 239 no.2755, Novo Hamburgo, RS 93352-000, Brazil.
}

RESUMO.- [Eficácia de uma vacina inativada, gE-deletada, contra o herpesvírus bovino tipo 1 (BoHV-1).] O Herpesvírus bovino tipo 1 (BoHV-1) é reconhecido como um importante agente de perdas econômicas em bovinos. Vacinação tem sido amplamente empregada para minimizar as perdas conseqüentes a infecções com o BoHV-1. Reportamos previamente o desenvolvimento de uma vacina diferencial para BoHV-1, baseada em um recombinante do qual a glicoproteína $\mathrm{gE}(\mathrm{gE})$ foi deletada $\left(265 \mathrm{gE}^{-}\right)$. No presente trabalho foi realizada a avaliação da eficácia de tal recombinante como vacina inativada. Cinco bovinos soronegativos para BoHV-1 foram vacinadas por via intramuscular no dia 0 e revacinadas 30 dias 
após com uma vacina inativada com adjuvante oleoso, contendo massa antigênica equivalente a $10^{7.0}$ doses infectantes para $50 \%$ dos cultivos celulares $\left(\right.$ DICC $\left._{50}\right)$ de $265 \mathrm{gE}^{-}$. Três animais foram mantidos como controles não vacinados. No dia 60 pós-vacinação, os animais vacinados e controles foram desafiados com a amostra virulenta parental. Nenhum sinal clínico ou efeito adverso foi observado após ou durante a vacinação. Após o desafio, 2 dos 5 animais vacinados apresentaram sinais leves de infecção, enquanto que todos os animais não vacinados apresentaram intensa rinotraqueíte e disseminaram vírus por mais tempo e em títulos mais elevados do que os animais vacinados. Respostas sorológicas foram detectadas em todos os animais vacinados depois da segunda dose de vacina, mas não nos animais do grupo controle. Após a administração de corticosteróide visando a reativação de infecções latentes, não foram observados sinais clínicos em nenhum dos 5 animais vacinados, enquanto os animais não vacinados apresentaram sinais leves de doença respiratória. Em vista de sua imunogenicidade e efeito protetor frente ao desafio com BoHV-1 virulento, a preparação oleosa com o recombinante $265 \mathrm{gE}^{-}$ inativado foi demonstrada ser adequada para uso como vacina.

TERMOS DE INDEXAÇÃO: Herpesvírus bovino tipo 1, BoHV1 , vacina recombinante, vacina inativada.

\section{INTRODUCTION}

Bovine herpesvirus 1 (BoHV-1), a member of the Alphaherpesvirinae subfamily, commonly known as infectious bovine rhinotracheits (IBR) virus, is an important cause of losses to cattle industry worldwide. BoHV-1 has been associated to a number of clinical syndromes, including vulvovaginitis, balanopostitis, conjunctivitis, infertility and abortions (Gibbs \& Rweyemamu 1977). The BoHV-1 genome consists of a linear dsDNA molecule of about $140 \mathrm{~Kb}$ (Schwyzer \& Ackermann 1996). It encodes several glycoproteins that are expressed on the viral envelope and membranes of infected cells. While some of these are essential for virus replication (Rebordosa et al. 1996), other glycoproteins are not essential for virus replication and represent potential targets for deletions aiming the development of differential vaccines. These vaccines have an advantage over the conventional vaccines because the serological response induced by vaccination can be differentiated from that induced by the wild type virus, allowing identification of wild type virus-infected animals in a herd. Glycoprotein $\mathrm{E}(\mathrm{gE})$ is one of such non-essential proteins (Rebordosa et al. 1996, Franco et al. 2002a, Spilki et al. 2004). Although it is conserved among other members of the Herpesviridae family, the role of $\mathrm{gE}$ in the in vitro growth characteristics may vary in function of the virus species and the host cell (Balan et al. 1994). In human herpesvirus type $1(\mathrm{HHV}-1)$ and varicella-zoster virus (HHV-3), gE can be found non-covalently linked to gl, forming a Fc binding site for immunoglobulins, which has been proposed as a mechanism to protect virus-infected cells from lysis by the immune system (Olson et al. 1997). The gE complex in HHV-1 and HHV-3 is also important for in vitro cell-to-cell spread (Balan et al. 1994, Dingwell et al. 1995). In comparison to wild type viruses, gE negative recombinants $\left(\mathrm{gE}^{-}\right)$produce smaller plaque sizes in vitro, although the growth kinetics or penetration process of the virus seem not to be dependent on the presence of $\mathrm{gE}$ (Rebordosa et al. 1996, Chowdhury et al. 1999, Spilki et al. 2004)

In previous studies, we described the construction of a recombinant vaccine, based on a Brazilian BoHV-1 isolate, from which the $\mathrm{gE}$ gene was deleted. This virus was named $265 \mathrm{gE}^{-}$and evaluated in vaccination/challenge experiments (Franco et al. 2002a). The live $265 \mathrm{gE}^{-}$virus based vaccine significantly reduced clinical signs of disease and virus shedding from vaccinated/challenged calves (Franco et al. 2002b). However, inactivated vaccine preparations may be considered safer in some instances, and may be favoured in relation to modified live attenuated virus vaccines. In order to check whether vaccination with inactivated $265 \mathrm{gE}^{-}$would be safe and induce protection to BoHV-1 infections, in the present study calves were vaccinated with an inactivated $265 \mathrm{gE}^{-}$based vaccine (Franco et al. 2002a,b), and challenged with the parental BoHV-1 wild type strain. Subsequently, vaccinated calves were submitted to corticosteroid administration to examine the capacity of the vaccine to avoid the establishment and the reactivation of a latent infection.

\section{MATERIALS AND METHODS}

\section{Experimental design}

Five calves were vaccinated twice with the recombinantbased inactivated vaccine on days 0 and 30 . Three others calves were kept as non-vaccinated controls for subsequent challenge and comparative analyses. Two additional calves were kept as non-vaccinated, non-challenged controls throughout the experiment. On day 60 post vaccination, vaccinated and nonvaccinated calves were challenged with the wild type parental virus. Two months after challenge, all calves were subjected to the corticosteroid administration in attempting to reactivate latent virus. Throughout the experiments the clinical scores were evaluated; swabs (ocular/ nasal) and serum samples were collected for further analysis of viral excretion and neutralizing antibodies production.

\section{Cells and viruses}

The wild type BoHV-1 strain SV 265 (SV 265wt), was isolated from a heifer with signs of respiratory infection in São Borja, Rio Grande do Sul, Brazil (Weiblen et al. 1996). The virus was used for the construction of the recombinant virus $\left(265 \mathrm{gE}^{-}\right)$as described previously (Franco et al. 2002a). The SV 265 was also used in the challenge experiments. Virus multiplication, titration and isolation from tissues as well as neutralization assays were performed on Madin Darby bovine kidney cells (MDBK, ATCC CCL-22). Cells were routinely maintained in Eagle's minimal essential medium (E-MEM) supplemented with $10 \%$ fetal calf serum (FCS, Nutricell) and $2 \mathrm{mg} / \mathrm{L}$ enrofloxacin (Baytril, Bayer). 


\section{Vaccine production}

About 16-24 hours after seeding of the cells, the medium was removed and bottles infected with recombinant virus $\left(265 \mathrm{gE}^{-}\right)$. After one hour adsorption at $37^{\circ} \mathrm{C}$, the inoculum was removed, the bottles replenished with E-EMEM without fetal calf serum and incubated for $16-24$ hours at $37^{\circ} \mathrm{C}$, when cytopathic effect was evident in $90 \%$ of the monolayers. Bottles were then shaken to remove attached cells and stored at $4^{\circ} \mathrm{C}$ for 24 hours. Infectious titres of the supernatants of infected cultures were determined following standard procedures (House \& Baker 1971). The viral suspension was inactivated with binary ethylenimine (BEI) as described previously (Bahnemann et al. 1974). The vaccine was prepared as a water-in-oil type emulsion and subjected to usual controls, as recommended (Petzhold et al. 2001) and the suspension was stored at $4^{\circ} \mathrm{C}$ until use. The inactivation process was evaluated by titration of the inactivated suspension in a 96 wells plate, followed by the inoculation of serial tenfold dilutions of the suspension in $25 \mathrm{~cm}^{2}$ cell culture flasks, according to usual methods. As positive control, an aliquot of the same viral suspension previous to inactivation was used in both procedures.

\section{Vaccination, challenge and viral reactivation of calves}

Five BoHV-1 seronegative calves, three to four months old, were vaccinated with an inactivated vaccine preparation containing (before inactivation) $10^{7.0}$ fifty percent cell culture infectious doses $\left(\mathrm{CCID}_{50}\right)$ of the recombinant $265 \mathrm{gE}$-. The vaccine dose was $3 \mathrm{~mL}$, which were administered intramuscularly. After 30 days the vaccination procedure was repeated. Three other calves were kept as non vaccinated controls for subsequent challenge. Two additional calves were kept as non vaccinated, non challenged controls throughout the experiment. On day 60 post vaccination, vaccinated and non vaccinated calves were challenged with $10^{7.0} \mathrm{CCID}_{50}$ of the parental virus SV265wt, in a $2 \mathrm{~mL}$ administered intranasally, $1 \mathrm{~mL}$ into each nostril. Two months after challenge, all calves were subjected to corticosteroid administration in attempting to reactivate latent virus. Dexamethasone $(0.26 \mathrm{mg}$ per $\mathrm{kg}$ of body weigh) was administered intramuscularly for 5 consecutive days as described previously (Caron et al. 2002). Calves were kept under observation and samples collected as described below.

All procedures involving animal care, handling and experiments were performed under veterinary supervision and according to the recommendations of the Brazilian Committee on Animal Experimentation (COBEA; law no. 6.638 of May 8, 1979).

\section{Clinical examination}

Clinical examinations were performed daily from day 10 prior to challenge and reactivation up to days 21 post-challenge (pc) and as well as on days 1 to 21 post-reactivation (pr). Rectal temperature (fever was defined as a rectal temperature of more than $39.5^{\circ} \mathrm{C}$ ), respiratory rates, clinical signs (coughing, congestion of the nasal mucosa, conjunctivitis, ocular and nasal discharges, changes in behaviour and appetite) as well as the presence of lesions on the nasal and oral mucosa were carefully examined.

\section{Virological examination}

Nasal and ocular swabs were collected daily from days 0 to 21 pc, 10 days before the beginning of dexamethasone administration and on days 1 to $21 \mathrm{pr}$. Swabs were immersed in $2 \mathrm{~mL}$ sterile E-MEM supplemented with $200 \mathrm{U} / \mathrm{mL}$ penicillin, 200 $\mu \mathrm{g} /$
$\mathrm{mL}$ streptomycin and $5 \mu \mathrm{g} / \mathrm{mL}$ Amphotericin B. Samples were stored at $-70^{\circ} \mathrm{C}$ until processing. Infectious titres of positive samples were determined, calculated and expressed as $\log _{10}$ $\mathrm{CCID}_{50}$ per $\mathrm{mL}$ after 72 hours of incubation at $37^{\circ} \mathrm{C}$.

\section{Immunoperoxidase monolayer assay (IPMA)}

To confirm the identify of the viruses recovered from nasal and ocular secretions, an immunoperoxidade monolayer assay was performed. The supernatants were inoculated on 96 well plates containing pre-formed MDBK monolayers, fixed in $4 \%$ paraformaldehyde and stained in an immunoperoxidase monolayer assay (IPMA) as previously described (Kramps et al. 1996), with an anti-BoHV-1 monoclonal antibody (MAb) as primary antibody (MAb 11H6; Souza et al. 2002).

\section{Virus neutralization tests}

Serum samples were collected on days 0, 30, 60 postvaccination (pv), and on days $0,7,14$ and $21 \mathrm{pc}$ and $\mathrm{pr}$. Neutralizing antibodies in serum samples were determined in a varying serum-constant virus neutralization (VN) assay (House \& Baker 1971), with twofold dilutions of serum against 100 $\mathrm{CCID}_{50}$ of BoHV-1 SV265 wt. Antibody titres were expressed as the reciprocal of the highest serum dilution that prevented the development of cytopathic effect (CPE) after 72 hours of incubation at $37^{\circ} \mathrm{C}$.

\section{Statistical analysis}

Statistical analysis was performed using the Student $t$-test or the analysis of variance (ANOVA). The least significant difference for $p=0.05$ was determined. Comparisons were made from day to day within the groups and between groups. Statistical analysis was performed with Data Analysis Supplement for Excel $^{\mathrm{tm}}$ (Office System 2003 for Windows ${ }^{\mathrm{tm}}$, Microsoft Corp., Seattle, USA). The term "significant" (statistically significant) means $p \leq 0.05$.

\section{RESULTS}

\section{Vaccination}

No clinical signs or adverse effects were seen after or during vaccination. All animals were clinically healthy and no signs of respiratory disease were observed before challenge.

\section{Clinical and virological findings following the challenge}

Among the vaccinated calves, between days 4 and 10 pc, mild clinical signs of respiratory disease (mild nasal lesions, nasal discharge, sneezing, coughing) were evident in $2 / 5$ calves. The other three vaccinated animals showed no clinical signs of respiratory disease throughout the experiment. Pirexia was not observed among vaccinated calves (Fig.1a). All vaccinated animals eliminated virus from nasal secretions from days 2 to $6 \mathrm{pc}$. The virus titres varied from $10^{0.75}$ to $10^{5.75} \mathrm{CCID}_{50} / \mathrm{mL}$ (Fig.2a, Table 1). Ocular virus shedding was detected from day 4 on in the vaccinated group. The maximum virus titre was obtained at days 6 and $8 \mathrm{pc}\left(10^{0.75} \mathrm{CCID}_{50} / \mathrm{mL}\right.$ and $10^{4.0} \mathrm{CCID}_{50} /$ mL, Fig.3a, Table 1).

All non vaccinated calves (3/3) developed severe clinical signs of illness. Apathy, anorexia, rhinitis with redness of the nasal mucosa, nasal and ocular discharges, 


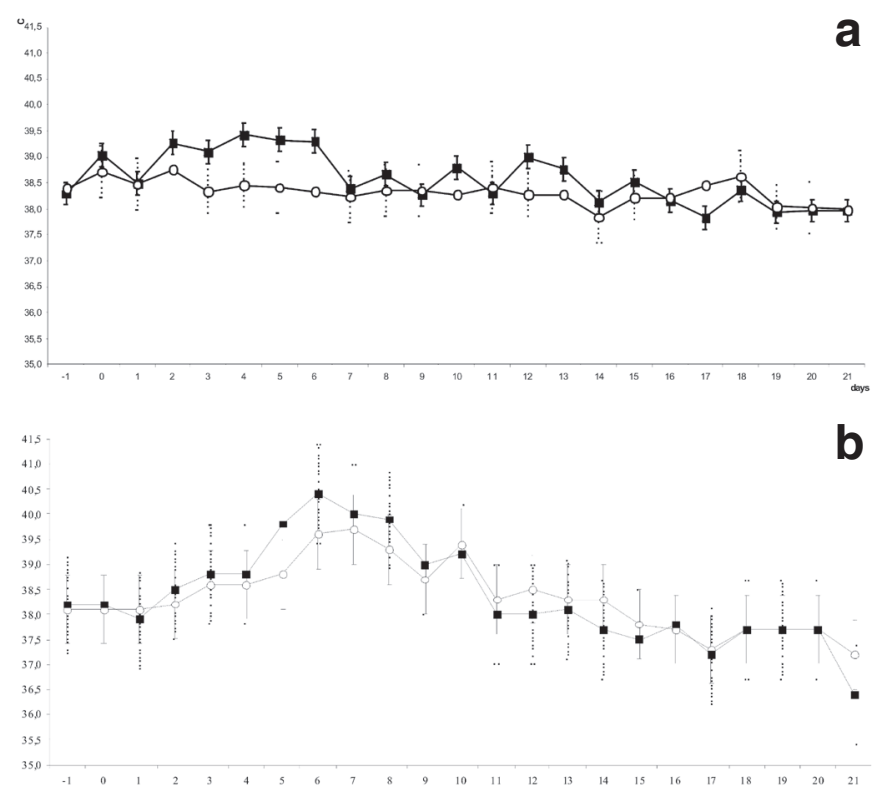

Fig.1. Mean rectal temperatures $\left({ }^{\circ} \mathrm{C}\right)(\mathbf{a})$ after challenge and $(\mathbf{b})$ after dexamethasone administration of vaccinated BoHV-1 gE- inactivated (empty circles) and non vaccinated calves (black squares). "Days" refers to days after challenge (a) or following dexamethasone administration (b). Vertical bars = standard deviation.

formation of vesicles with tendency to coalescence and erosions on the nasal mucosa, conjunctivitis, nasal stridor, sneezing and spontaneous coughing were observed in all non vaccinated calves. Dyspnea and tracheal stridors were observed in different degrees. On day $2 \mathrm{pc}$, the rectal temperatures of the infected calves started to rise. Fever $\left({ }^{3} 39.5^{\circ} \mathrm{C}\right)$ was recorded from days 3 to 5 (Fig.1a). Despite severely ill on days 3 to $8 \mathrm{pc}$, all calves completely recovered from primary infection $13 \mathrm{dpc}$ without noticeable sequels. Virus shedding was detected in nasal secretions from day $2 \mathrm{pc}$ on all non vaccinated calves. However, the period of viral excretion was longer and the amount of virus shed among the non vaccinated group virus was to higher titres in comparison with the vaccinated calves (up to $10^{5.75}$ $\mathrm{CCID}_{50} / \mathrm{mL}$; Fig.2a, Table 1). Ocular virus shedding was

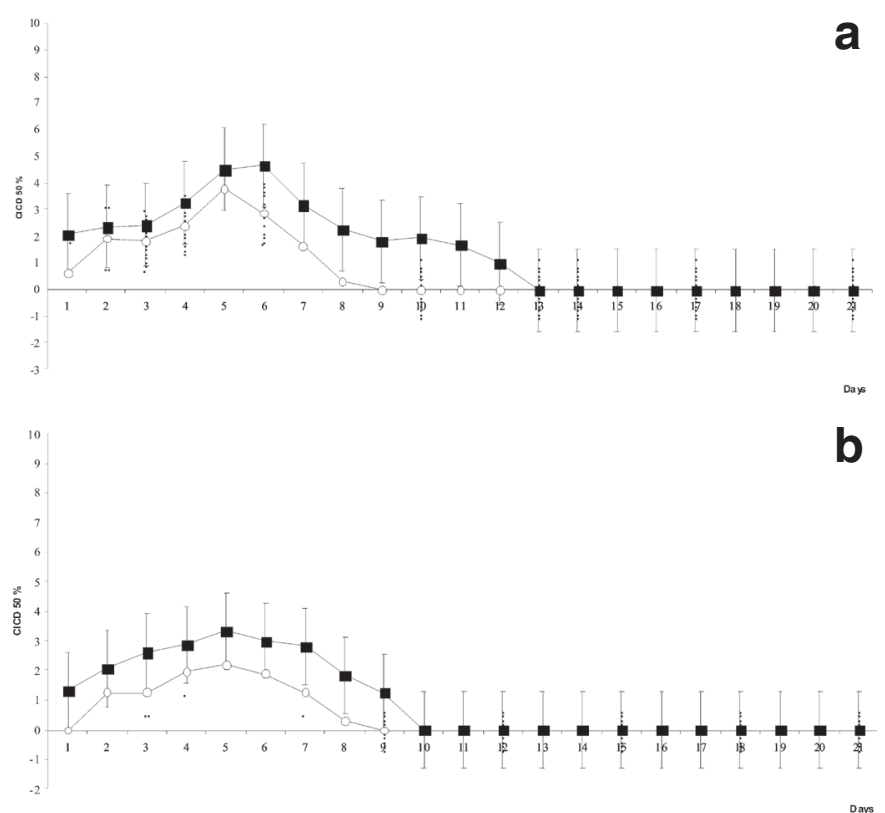

Fig.2. Nasal virus shedding: (a) after challenge with wild type virus (SV265wt) challenge; (b) after dexamethasone administration. Infectious virus titres expressed in $\log _{10}$ of $50 \%$ cell culture infectious doses per $\mathrm{mL}\left(\mathrm{CCID}_{50}\right)$. Empty circles: vaccinated calves; black squares: non vaccinated calves. Vertical bars = standard deviation.

initially detected on day $2 \mathrm{pc}$ (one animal) in the group of non vaccinated animals and the maximum virus titres were detected at days 5 and $8 \mathrm{pc}\left(10^{2.75} \mathrm{CCID}_{50} / \mathrm{mL}\right.$ and $10^{5.75}$ $\mathrm{CCID}_{50} / \mathrm{mL}$ respectively). From then on the titres tended to decrease until day $21 \mathrm{pc}$ when sampling was discontinued (Fig.3a, Table 1). Calves of the negative control group remained healthy and did not shed virus in nasal secretions during the experiment.

\section{Clinical and virological findings following reactivation attempts}

Following dexamethasone administration, vaccinated calves did not develop clearly noticeable signs of respiratory disease, whereas only mild clinical signs of disease were observed in non vaccinated calves. However, such signs

Table 1. Viral shedding in nasal and ocular secretions from vaccinated and non vaccinated calves following challenge with wild type parental virus

\begin{tabular}{|c|c|c|c|c|c|c|c|c|c|c|c|c|c|c|c|}
\hline \multirow[t]{3}{*}{ Group } & \multicolumn{15}{|c|}{ Viral shedding } \\
\hline & \multicolumn{15}{|c|}{ Day post challenge ${ }^{a}$} \\
\hline & Animal & Site & 1 & 2 & 3 & 4 & 5 & 6 & 7 & 8 & 9 & 10 & 11 & 12 & $13-21$ \\
\hline \multirow{5}{*}{$\begin{array}{l}\text { Vaccinated } \\
\text { animals }\end{array}$} & 57 & NO & - & +- & +- & ++- & ++++ & ++++ & +++ & -++ & -+ & - & - & - & - \\
\hline & 65 & NO & - & ++- & ++- & +++ & +++++ & ++++ & ++ & ++ & - & - & - & - & - \\
\hline & 64 & NO & ++- & +- & ++- & +- & +++ & +++ & ++++ & -+ & - & - & - & - & - \\
\hline & 60 & NO & - & +- & +- & +++ & +++++ & +++++ & ++++ & -+ & -+ & - & - & - & - \\
\hline & 61 & NO & - & - & +- & +- & ++ & ++ & -+ & ++ & - & - & - & - & - \\
\hline \multirow{3}{*}{$\begin{array}{l}\text { Non vaccinated } \\
\text { animals }\end{array}$} & 67 & NO & ++- & +- & +++ & +++ & +++++ & +++++ & +++++++ & +++++ & ++++ & ++++ & +++ & ++ & - \\
\hline & 63 & NO & +++- & ++++ & ++++ & ++++ & ++++ & +++++ & +++++++ & +++++ & +++++ & ++++ & ++ & ++ & - \\
\hline & 59 & NO & - & +- & +++ & +++++ & +++++ & +++++ & ++++ & ++++ & ++++ & +++ & +++ & ++ & - \\
\hline
\end{tabular}

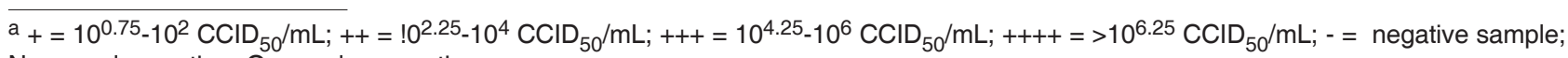
$\mathrm{N}=$ nasal secretion; $\mathrm{O}=$ ocular secretion 


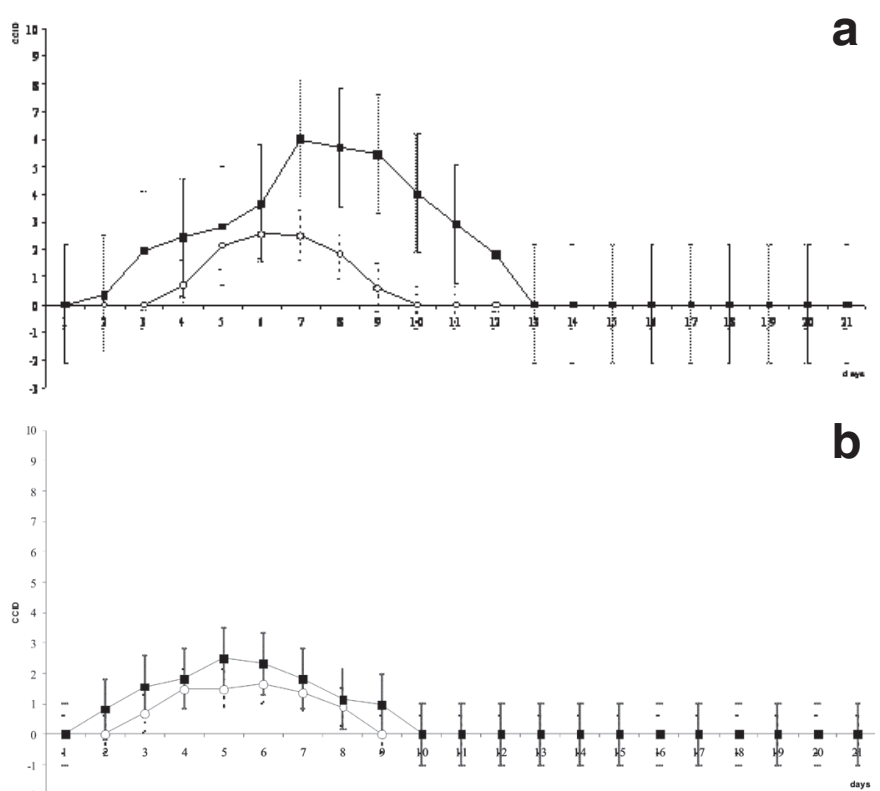

Fig.3. Ocular virus shedding: (a) after challenge with wild type virus (SV265wt) challenge, and (b) after dexamethasone administration. Infectious virus titres expressed in $\log _{10}$ of $50 \%$ cell culture infectious doses per $\mathrm{mL}\left(\mathrm{CCID}_{50}\right)$. Empty circles: vaccinated calves; black squares: non vaccinated calves. Vertical bars $=$ standard deviation.

were less intense than those observed during primary infection. All non vaccinated calves were pyrexic from days 5 to 8 pr. (Fig.1b), whereas only two vaccinated calves presented fever for two days. Nasal virus shedding in the group of non vaccinated calves was detected from days 1 to $9 \mathrm{pr}$, and to higher titres than on vaccinated calves, which excreted virus from days 2-8 pr (until $10^{2.75} \mathrm{TCID}_{50} / \mathrm{mL}$; Fig.2b, Table1). Ocular virus shedding was detected from day 2 to $9 \mathrm{pr}$ in the non vaccinated calves and day 3 to $8 \mathrm{pr}$ in the vaccinated calves (Fig.3b, Table 1).

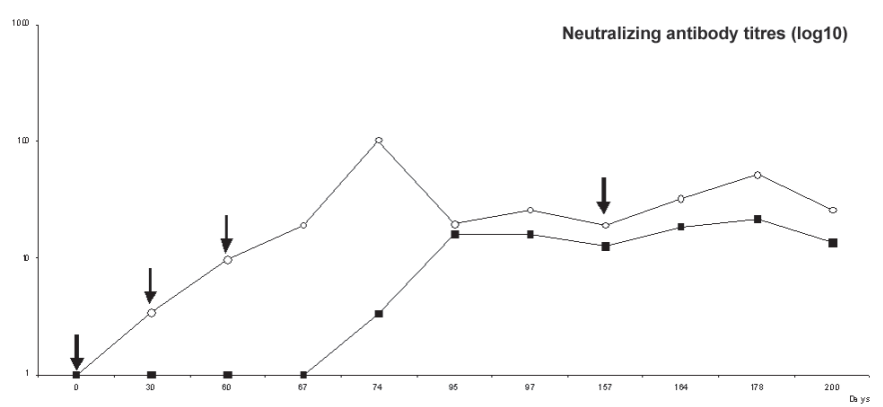

Fig.4. Neutralizing antibody titres (geometric mean titres in each group) after immunization with an inactivated BoHV-1 265gEvaccine, challenge with wild type virus (SV265 wt) and during reactivation attempts with dexametasone administration. Empty circles: vaccinated calves; black squares: non vaccinated calves. Arrows points to date of immunization (day 0 first dose and day 30 second dose); challenge (60 day post vaccination) and date of the beginning of dexametasone administration (157 days post vaccination) respectively. Titres expressed as $\log _{10}$ of the reciprocal of the neutralizing antibody titres.
Table 2. Virus neutralizing antibodies in vaccinated and non vaccinated calves following vaccination, challenge and dexamethasone (Dx) administration. Titres expressed as the reciprocal of the neutralizing antibody titre

\begin{tabular}{lccccccc}
\hline \multirow{2}{*}{ Groups } & Animals & \multicolumn{5}{c}{ Virus neutralizing titres } \\
\cline { 3 - 8 } & & $\begin{array}{c}\text { Days post } \\
\text { vaccination }\end{array}$ & \multicolumn{2}{c}{$\begin{array}{c}\text { Days post } \\
\text { challenge }^{\mathrm{a}}\end{array}$} & $\begin{array}{c}\text { Days post Dx } \\
\text { treatment }^{\mathrm{b}}\end{array}$ \\
\cline { 3 - 8 } & 0 & 60 & 14 & 37 & 7 & 43 \\
\hline Vaccinated & 57 & $<2$ & 8 & 64 & 32 & 16 & 16 \\
animals & 60 & $<2$ & 8 & 128 & 16 & 64 & 32 \\
& 61 & $<2$ & 8 & 128 & 16 & 16 & 32 \\
& 64 & $<2$ & 16 & 128 & 32 & 32 & 16 \\
Non vaccinated & 65 & $<2$ & 8 & 64 & 32 & 32 & 32 \\
animals & 67 & $<2$ & $<2$ & $<2$ & 8 & 8 & 16 \\
& 63 & $<2$ & $<2$ & 8 & 32 & 32 & 8 \\
& 59 & $<2$ & $<2$ & $<2$ & 8 & 16 & 16
\end{tabular}

a Challenge occurred on day 60 post vaccination.

b Dexametasone treatment started on day 157 post vaccination.

\section{Neutralizing antibody responses}

None of the calves had detectable BoHV-1 neutralizing antibodies previous to the experiments. Unvaccinated animals remained BoHV-1 seronegative until challenge. After the first vaccination, $4 / 5$ vaccinated animals started to produce neutralizing antibodies. After the booster administration, all calves seroconverted. The mean antibody titre obtained after the second dose of vaccine in all vaccinated animals showed a marked increase in comparison to the titres obtained after the first dose of vaccine. After challenge, again a boost in BoHV-1 neutralizing antibody titres was detected in all vaccinated calves, which revealed higher antibody titres after challenge than non vaccinated calves (Fig.4, Table 2). Control calves remained negative for neutralizing antibodies throughout the experiment.

\section{DISCUSSION}

A gE- BoHV-1 was previously developed and tested as a live vaccine (Franco et al. 2002a). As inactivated vaccines may be considered safer to use - particularly because these pose virtually no risk of virus reversion - our aim here was to evaluate the clinical, virological and serological findings on animals inoculated with an inactivated vaccine prepared with the same $265 \mathrm{gE}^{-}$recombinant, in a vaccination/ challenge experiment.

Vaccination of calves with the inactivated vaccine preparation was considered safe for use in calves since it did not cause any noticeable adverse effects on inoculated animals. After intranasal challenge with the wild type virus, only two vaccinated calves had a mild increase in body temperature and mild local signs of infection (few small erosions, nasal secretion and a slight increase in the respiratory frequency) were observed in two out of five calves. On the other hand, non vaccinated control calves developed severe signs of infection at the site of wild type virus inoculation (nostrils) and systemic signs of disease after challenge. This indicates that the challenge virus was still able to infect the nasal epithelium of vaccinated animals 
but was not detected in the lower respiratory system, nor did it cause systemic signs of infection (fever, anorexia, apathy). These results confirm that a significant protection to clinical disease was attained after vaccination. The clinical protection against challenge with wild type virus was comparable to the protection obtained with the attenuated vaccine (Franco et al. 2002b). These results are also comparable with those of previous workers with another, similarly built, inactivated $\mathrm{gE}^{-}$virus vaccine (Kaashoek et al. 1995).

In the present experiment, after challenge, vaccinated calves shed wild type virus in nasal and ocular secretions to lower titres and for a shorter period of time than did non vaccinated calves (Fig.2a, Fig.3a, Table 1). Thus, the inactivated preparation was as efficacious as the attenuated recombinant vaccine formulation in reducing virus shedding in nasal and ocular secretions (Franco et al. 2002b). Reduction in challenge virus shedding, though not always linked to clinical protection, is important for the reduction of virus circulation within a herd, or between herds (Van Oirschot 1999).

Although the differential properties of this viral vaccine could not yet be shown because of the lack of commercial serologic tests in Brazil that can differentiate the immune responses of vaccinated and naturally infected animals, the immune responses during this experiment were measured using the virus neutralization test. Although the presence of neutralizing antibodies in serum does not necessarily correlate with reduction of virus shedding or clinical protection in BoHV-1 vaccinated animals, induction of virus neutralizing antibodies is very often used to access immune responses to vaccination (Kramps et al. 2004, Patel et al. 2005, Silva et al. 2007). The neutralizing antibody titers obtained after two doses of the inactivated $265 \mathrm{gE}^{-}$vaccine were higher than those detected after vaccination with one dose of the attenuated vaccine prepared with the same recombinant (Franco et al. 2002a). Similar observations were reported previously with another gE- vaccine (Kaashoek et al. 1995). Such differences were probably derived from the fact that the calves immunized with the attenuated virus received a single vaccine dose, whereas the inactivated vaccine was administered twice.

After the reactivation attempt with dexamethasone, vaccinated calves did not show noticeable clinical signs. Latency was, nevertheless, established, since vaccinated calves did shed virus in their secretions, albeit for a shorter period and to lower titers than non vaccinated calves. These results indicate that the vaccine did not block the establishment of latent infection by the wild type challenge virus. Consonant with that, previous studies have shown that live, inactivated, conventional or subunit BoHV-1 vaccines, did not prevent the establishment of latency (Ackermann \& Engels 2006). However, virus reactivation was less prominent in vaccinated animals than in controls, a desirable effect of vaccination, since it will reduce virus circulation in the herd.
Analysis of the data presented here show that the inactivated, oil adjuvanted vaccine prepared with the $265 \mathrm{gE}^{-}$recombinant is safe and efficacious in minimizing clinical signs when vaccinated calves were challenged with an expressive amount $\left(10^{7.0} \mathrm{CCID}_{50}\right)$ of virulent wild type BoHV-1. Such preparation must be evaluated further in order to determine its applicability in controlling BoHV1 infections in the field.

Acknowledgements.- A.D. Silva and P.A. Esteves were students from the Programa de Pós-Graduação em Ciências Veterinárias da Faculdade de Veterinária (PPGCV/UFRGS/Brazil) grantees of CAPES. P.M. Roehe is a CNPq $1 \mathrm{C}$ research fellow. This study was supported by CNPq, PRONEX, FAPERGS and CAPES.

\section{REFERENCES}

Ackermann M. \& Engels M. 2006. Pro and contra IBR-eradication. Vet. Microbiol. 113(3/4):293-302.

Bahnemann H., Augé De Mello P., Abaracon D. \& Goe S.I. 1974. Immunogenicity in cattle of foot and mouth disease vaccines inactivated with binary ethylenimine. Bull. Off. Int. Epiz. 81:1335-1343.

Balan P., Davis-Poynter N., Bell S., Atkinson H., Browne H. \& Minson T. 1994. An analysis of the in vitro and in vivo phenotypes of mutants of herpes simplex virus type 1 lacking lycoproteins $\mathrm{gG}, \mathrm{gE}, \mathrm{gl}$ or the putative gJ. J. Gen. Virol. 75( Pt 6):1245-1258.

Caron L., Flores E.F., Weiblen R., Scherer C.F., Irigoyen L.F., Roehe P.M., Odeon A. \& Sur J.H. 2002. Latent infection by bovine herpesvirus type-5 in experimentally infected rabbits: virus reactivation, shedding and recrudescence of neurological disease. Vet. Microbiol. 84(4):285295.

Chowdhury S.I., Ross C.S., Lee B.J., Hall V. \& Chu H.J. 1999. Construction and characterization of a glycoprotein $\mathrm{E}$ gene-deleted bovine herpesvirus type 1 recombinant. Am. J. Vet. Res. 60(2):227-232.

Dingwell K.S., Doering L.C. \& Johnson D.C. 1995. Glycoproteins E and I facilitate neuron-to-neuron spread of herpes simplex virus. J. Virol. 69 (11):7087-7098.

Gibbs E.P.J. \& Rweyemamu M.M. 1977. Bovine herpesvirus. Part I. Bovine herpesvirus 1. Vet. Bull. 47:317-343.

House J.A. \& Baker J.A. 1971. Bovine herpesvirus IBR-IPV: The antibody virus neutralization reaction. Cornell Vet. 61:320-335.

Kaashoek M.J., Moerman A., Madic J., Weerdmeester K., Maris-Veldhuis M., Rijsewijk F.A. \& van Oirschot J.T. 1995. An inactivated vaccine based on a glycoprotein E-negative strain of bovine herpesvirus 1 induces protective immunity and allows serological differentiation. Vaccine 13(4):342-346.

Kramps J.A., Perrin B., Edwards S. \& van Oirschot J.T. 1996. A European inter-laboratory trial to evaluate the reliability of serological diagnosis of bovine herpesvirus 1 infections. Vet. Microbiol. 53(1/ 2):153-161

Kramps J.A., Banks M., Beer M., Kerkhofs P., Perrin M., Wellenberg G.J. \& Oirschot J.T. 2004. Evaluation of tests for antibodies against bovine herpesvirus 1 performed in national reference laboratories in Europe. Vet. Microbiol. 102(3/4):169-81.

Franco A.C., Rijsewijk F.A.M., Flores E.F., Weiblen R. \& Roehe P.M. 2002a. Construction and characterization of a glycoprotein $E$ deletion mutant of bovine herpesvirus type 1.2 strain isolated in Brazil. Braz. J. Microbiol. 33:274-278.

Franco A.C., Spilki F.R., Esteves F.R., Lima M., Weiblen R., Flores E.F., Rijsewijk F.A.M. \& Roehe P.M. 2002b. A Brazilian glycoprotein $\mathrm{E}$ negative bovine herpesvirus type 1.2a (BHV-1.2a) mutant is attenuated for cattle and induces protection against wild-type virus challenge. Pesq. Vet. Bras. 22:135-140. 
Murphy F.A., Gibbs E.P., Horzinek M.C. \& Studdert M.J. 1999. Veterinary Virology. 3rd ed. Academic Press, New York.

Olson J.K., Bishop G.A. \& Grose C. 1997.Varicella-zoster virus Fc receptor gE glycoprotein: serine/threonine and tyrosine phosphorylation of monomeric and dimeric forms. J. Virol. 71(1):110-119.

Petzhold S.A., Reckziegel P.E., Prado J.A.,Teixeira J.C., Wald V.B., Esteves PA., Spilki F.R. \& Roehe P.M. 2001. Neutralizing antibodies to bovine herpesviruses types 1 (BHV-1) and 5 (BHV-5) induced by an inactivated vaccine to BHV-1. Braz. J. Vet. Res. Anim. Sci. 38(3):184-187.

Rebordosa X., Pinol J., Perez-Pons J.A., Lloberas J., Naval J., SerraHartmann X., Espuna E. \& Querol E. 1996. Glycoprotein E of bovine herpesvirus type 1 is involved in virus transmission by direct cell-tocell spread. Virus Res. 45(1):59-68.

Schwyzer M. \& Ackermann M. 1996. Molecular virology of ruminant herpesviruses. Vet. Microbiol. 53:17-29.

Spilki F.R., Franco A.C., Rijsewijk F.A.M., Weiblen R., Flores E.F. \& Roehe P.M. 2004. In vitro characterization of gE negative Bovine
Herpesvirus Types 1.1 (BHV-1.1) and 1.2 (BHV-1.2). Braz. J. Microbiol. 35:264-268.

Silva L.F., Weiblen R. \& Flores E.F. 2007. Imunogenicidade de vacinas comerciais inativadas contra Herpesvirus Bovino tipo 1. Ciência Rural 37(5):471-1474.

Souza V.F., Melo S.V., Esteves P.A., Schmidt C.S.R., Gonçalves D.A., Schaefer R., Silva T.C., Almeida R.S., Vicentini F., Franco A.C., Oliveira E.A., Spilki F.R., Weiblen R., Flores E.F., Lemos R.A., Alfieri A.A., Pituco E.M. \& Roehe P.M. 2002. Caracterização de herpesvírus bovinos tipos 1 (BHV-1) e 5 (BHV-5) com anticorpos monoclonais. Pesq. Vet. Bras. 22(1):13-18.

Van Oirschot J.T., Kaashoek M.J., Maris-Veldhuis M.A. \& Rijsewijk F.A. 1999. Strains of bovine herpesvirus 1 that do not express an epitope on glycoprotein $E$ in cell culture still induce antibodies that can be detected in a gE-blocking ELISA. Vet. Microbiol. 65(2):103113.

Weiblen R., Moraes M.P., Rebelatto M.C., Lovato L.T. \& Canabarro T.F. 1996. Bovine herpesvirus isolates. Revta Microbiol. 27(3):87-90. 